\title{
Information Media Use Behavior of Vegetable Growers in Sylhet District, Bangladesh
}

\section{Das ${ }^{1}$, MR Amin ${ }^{2}$, MM Adhikary ${ }^{2 *}$ and M Rokonuzzaman ${ }^{3}$}

${ }^{1}$ MS Student, Department of Agricultural Extension Education, Sylhet Agricultural University, Sylhet, Bangladesh

${ }^{2}$ Professor, Department of Agricultural Extension Education, Sylhet Agricultural University, Sylhet, Bangladesh

${ }^{3}$ Professor (Retd), Department of Agricultural Extension and Former Vice-Chancellor, Bidhan Chandra Krishi Viswavidyalaya, West Bengal, India

*Corresponding Author: MM Adhikary, Professor, Department of Agricultural Extension Education, Sylhet Agricultural University, Sylhet, Bangladesh.

Received: September 19, 2019; Published: October 21, 2019

DOI: 10.31080/ASAG.2019.03.0695

\begin{abstract}
The main objective of the study was to assess farmers' behavior in using information media for vegetables cultivation. A total of 100vegetable growers of Biswanath Upazila (administrative unit) under Sylhet District of Bangladesh were selected through multistage simple random sampling technique and data were collected from them using pre-tested structured interview schedule. The result revealed that, majority (46.2) of the vegetable growers was exposed to individual information media compared to group and mass media in receiving information on vegetable cultivation. Among all the seventeen information media, neighbour, television, friends and relatives, mobile phone and contact with Sub Assistant Agriculture Officer were found the top most used source of information. Farmers age, family size, farm size, organizational participation, innovativeness, cosmopoliteness and agricultural knowledge had positive significant relationship with their use of information media where education, annual income, training and coping with uncertainty were found to have insignificant relationship.
\end{abstract}

Keywords: Information Media; Vegetables; Farmer; Cosmopoliteness

\section{Introduction}

Vegetables are very important group of crops grown in Bangladesh where fifty four different kinds of vegetables are now cultivating here. Bangladesh produce only 2.9 million metric tons of vegetables against the estimated requirement of 11.0 million metric tons from an area of 3.5 lac hectares (BBS, 2008-09). Although the country is facing a great challenge towards increasing productivity, the expected quantity only can be achieved if the vegetables growers can apply the modern practices in their fields. But the communication of modern and updated practices and technologies completely dependent on the use of various types of information media. In the past, the different information sources has played a significant role in modernization of agriculture. In future too, the agricultural extension work will depend much on information media for the dissemination of latest agricultural technologies to a large number of farmers in a shortest possible time. Oakley and Garforth [1] considered print media as permanent message senders in Agricultural Extension. Mosher [2] reported different print media like posters, pamphlets, leaflets etc. changed the behaviors of $98 \%$ farmers. Mehmmod [3] revealed print media and television as the most effective source of information used by the farmers. So it is now utmost important to explore the existing information media use behavior of the farmers so that they can be equipped with updated technologies in their working fields.

\section{Materials and Methods}

Vegetable growers of Bishwanath upazila were the population of the study. A total of 100 farm families (15\%) were selected as 
sample from four villages using multistage simple random sampling technique. Pre-tested interview schedule was used to collect data from the respondents. Descriptive statistics i.e. mean, frequency, standard deviation were used to summarize the data and Inferential statistics i.e. Pearson's product moment correlation co-efficient was used to explore the relationship between farmers socio-economic characteristics and their information media use behavior.

\begin{tabular}{|c|c|c|c|}
\hline Information media & Assigned score & $\begin{array}{c}\text { Information } \\
\text { Media }\end{array}$ & Assigned score \\
\hline \multirow[t]{3}{*}{ SAAO } & $0=$ Not even once a month & \multirow{3}{*}{$\begin{array}{c}\text { Result demonstration } \\
\text { Meeting at result demonstration } \\
\text { Method demonstration }\end{array}$} & $0=$ Not even once a month \\
\hline & $1=1$ time /two months & & $1=1-3$ times a month \\
\hline & $2=1$ or more times a month & & $2=4$ times or more a month \\
\hline \multirow[t]{3}{*}{ Poster } & $0=$ Not even once a month & \multirow{3}{*}{$\begin{array}{l}\text { Friends and Relatives } \\
\text { Neighbors } \\
\text { Mobile phone } \\
\text { Radio }\end{array}$} & $0=$ Not even once a month \\
\hline & $1=1-4$ times a year & & $1=1-9$ times a month \\
\hline & $2=5$ times or more a year & & $2=10$ times or more a month \\
\hline \multirow[t]{3}{*}{ KrishiKotha } & $0=$ Not even once a month & \multirow[t]{3}{*}{ Upazila Agriculture Officer } & $0=$ Not even once a month \\
\hline & $1=1-6$ times a month & & $1=1$ time $/$ two months \\
\hline & $2=7$ times or more a month & & $2=1$ or more times a month \\
\hline \multirow[t]{3}{*}{ Input dealers } & $0=$ Not even once a month & \multirow[t]{3}{*}{ Agricultural exhibition } & $0=$ Not even once $\mathrm{a}$ month \\
\hline & $1=1-7$ times a month & & $1=1-2$ times a year \\
\hline & $2=8$ times or more a month & & $2=3$ times or more a year \\
\hline \multirow[t]{3}{*}{ Field day } & $0=$ Not even once $\mathrm{a}$ month & \multirow[t]{3}{*}{ Internet } & $0=$ Not even once $\mathrm{a}$ month \\
\hline & $1=1-9$ times a year & & $1=1-2$ times a year \\
\hline & $2=10$ times or more a year & & $2=3$ times or more a year \\
\hline \multirow[t]{3}{*}{ Field trips } & $0=$ Not even once a month & \multirow[t]{3}{*}{ Television } & $0=$ Not even once a month \\
\hline & $1=1-4$ times a year & & $1=1-2$ timea a month \\
\hline & $2=5$ times or more a year & & $2=3$ times or more a month \\
\hline
\end{tabular}

Table 1: Scoring process of extent of contact with some selected information media.

Procedure for measuring the information media used by the vegetable growers were determined based on media used index (MUI) by using following formula.

MUI $=\mathrm{N} 1 \times 2+\mathrm{N} 2 \times 1+\mathrm{N} 3 \times 0$

Where, MUI= Media Used Index

$\mathrm{N} 1=$ Number of farmers regularly using the media.

$\mathrm{N} 2=$ Number of farmers occasionally using the media.

N3= Number of farmers who did not use the media at all.

The MUI was calculated by multiplying the assigned score of each of the media for respective scale and adding together.

\section{Result and Discussion}

Socio-economic characteristics of the respondents

- $\quad$ Age: The age of the vegetable growers ranged from 25 to 75 . The average of the vegetable growers was 42.56 years. The highest proportions (62\%) of the vegetable growers were in the middle aged category compared with $20 \%$ by young and $20 \%$ old aged.

- Education: Education of the vegetable growers ranged from 0 to 10 years of schooling. The highest proportion $(43 \%)$ of the vegetable growers had no education followed by $32 \%$ having primary education and $25 \%$ having secondary level of education. 
- Family size: Family size of the vegetable growers ranged from 3 to 13 . The average family size of the vegetable growers was 6.67. The highest proportion $81 \%$ of the settled families fell under the medium family category compared to $11 \%$ large family and remaining $8 \%$ with small family size category.

- Farm size: Farm size of the vegetable growers ranged from 0.09 to 1.45 hectares. The average farm size of the vegetable growers was 0.53 hectares. The highest proportion $((72 \%)$ of the vegetable growers had medium size farm compared with $15 \%$ having large farm size and remaining 13\% having small sized farm.

- Annual income: Annual income of the vegetable growers ranged from Taka 39000 to 190000 . Almost four-fifths (82\%) of the respondents had low income as compared with $17 \%$ having medium and only $1 \%$ having high income. The average per head income of the vegetable grower was Tk. 74065.00 which is higher than that of the national per capita average income in Bangladesh.
- Organizational participation: The organizational participation scores of the vegetable growers ranged from 0 to 18; the average of 4.35 . The highest proportion (42\%) of the vegetable growers had low participation in any organization compared with 32\% having no participation, 19\% having medium participation and only $7 \%$ having high participation.

- Innovativeness: The innovativeness score of the vegetable grower's ranged from 10 to 28; the average of 19.27. The highest participation (53\%) of the respondents had medium innovativeness compared with $24 \%$ having low and $23 \%$ having high innovativeness.

- Cosmopoliteness: The cosmopoliteness scores of the vegetable growers ranged from 0 to 7 ; the average of 4.06 . The highest proportion $(71 \%)$ of the vegetable growers had medium cosmopoliteness compared with $17 \%$ having high cosmopoliteness and $12 \%$ having low cosmopoliteness.

\begin{tabular}{|c|c|c|c|c|c|}
\hline Socio-economic characters & Frequency & Percent & Socio-economic characters & Frequency & Percent \\
\hline Age (years) & & & Medium participation (7-12) & 19 & 19.0 \\
\hline Young (up to 35) & 19 & 19.0 & High participation (13-18) & 7 & 7.0 \\
\hline Middle age ( $36-50$ years) & 62 & 62.0 & Mean & 4.35 & \\
\hline Old (above 50 years) & 19 & 19.0 & Standard Deviation & 4.51 & \\
\hline Mean & 42.56 & & Cosmopoliteness (score) & & \\
\hline Standard Deviation & 11.41 & & $\begin{array}{l}\text { Low cosmopoliteness (up to } \\
\text { 10) }\end{array}$ & 12 & 12.0 \\
\hline Education (score) & & & $\begin{array}{l}\text { Medium cosmopoliteness } \\
(11-20)\end{array}$ & 71 & 71.0 \\
\hline Illiterate $(0)$ & 43 & 43.0 & $\begin{array}{l}\text { High cosmopoliteness (above } \\
\text { 21) }\end{array}$ & 17 & 17.0 \\
\hline Primary (1-5) & 32 & 32.0 & Mean & 4.06 & \\
\hline Secondary (6-10) & 25 & 25.0 & Standard Deviation & 1.38 & \\
\hline Mean & 3.21 & & Training Experience (score) & & \\
\hline Standard Deviation & 2.87 & & No(0) & 24 & 24.0 \\
\hline Family size (members) & & & Low (1-7) & 39 & 39.0 \\
\hline Small (2 to 5) & 8 & 8.0 & Medium (8-14) & 31 & 31.0 \\
\hline Medium (6 to 9) & 81 & 81.0 & High (15 and above) & 25 & 25.0 \\
\hline Large (10 and above) & 11 & 11.0 & Mean & 6.35 & \\
\hline Mean & 6.67 & & Standard Deviation & 4.60 & \\
\hline Standard Deviation & 1.74 & & Innovativeness (score) & & \\
\hline Farm Size (ha) & & & Low(up to 10.33 ) & 24 & 14.0 \\
\hline
\end{tabular}




\begin{tabular}{|c|c|c|c|c|c|}
\hline & & & Medium (10.34 to 16.67$)$ & 53 & 53.0 \\
\hline Small (0.09-0.294) & 13 & 13.0 & High ( above 16.68) & 23 & 23.0 \\
\hline Medium (0.295-0.752) & 72 & 72.0 & Mean & 19.27 & \\
\hline Large ( 0.753 and above) & 15 & 15.0 & Standard Deviation & 4.46 & \\
\hline Mean & 0.52 & & $\begin{array}{l}\text { Agricultural knowledge } \\
\text { (score) }\end{array}$ & & \\
\hline Standard Deviation & 0.23 & & Low(up to 11 ) & 2 & 2.0 \\
\hline Annual Income (score) & & & Medium(12 to 17$)$ & 45 & 45.0 \\
\hline Low income (upto 328) & 82 & 82.0 & High ( above 23) & 53 & 53.0 \\
\hline Medium income (329-648) & 17 & 17.0 & Mean & 31.63 & \\
\hline High income (above 648) & 1 & 1.0 & Standard Deviation & 4.19 & \\
\hline Mean & 74.06 & & $\begin{array}{l}\text { Coping with uncertainty } \\
\text { (score) }\end{array}$ & & \\
\hline Standard Deviation & 22.35 & & Low (3-3.9) & 6 & 6.0 \\
\hline $\begin{array}{l}\text { Organizational Participation } \\
\text { (score) }\end{array}$ & & & Medium (4-4.99) & 35 & 35.0 \\
\hline Low participation (0) & 32 & 32.0 & High (5 and above) & 59 & 59.0 \\
\hline \multirow[t]{2}{*}{ Low participation (1-6) } & 42 & 42.0 & Mean & 4.65 & \\
\hline & & & Standard Deviation & 0.49 & \\
\hline
\end{tabular}

Table 2: Socio-economic characteristics of the respondents.

\section{Training}

The training experience ranged from 0 to 20; the average of 6.35. The highest 39\% respondents had low training experience compared with $31 \%$ of the respondents had medium training, $24 \%$ had no training experience at all and only $6 \%$ of the respondents had long duration training experience

\section{Coping with uncertainty}

The computed coping with uncertainty scores of the vegetable growers ranged from 3 to 5 with a mean score of 4.65 and standard deviation of 0.49 . The highest proportion (59\%) of the vegetable growers had high capacity of coping with uncertainty compared with $35 \%$ having medium and $6 \%$ having low capacity of coping with uncertainty.

\section{Knowledge in vegetable cultivation}

Knowledge in vegetable cultivation scores of the vegetable growers ranged from 10 to 40 against the possible range from 0 to 36 where mean was 31.63 with the standard deviation of 4.189 . The highest proportion (53\%) of the vegetable growers had high knowledge in vegetable cultivation compared with $45 \%$ having medium knowledge in vegetable cultivation and only $2 \%$ having low knowledge in vegetable cultivation.

Extent of information media used by the vegetable growers in receiving information on vegetable cultivation

Extent of use of the different information media was measured based on the media use index (MUI). The computed MUI ranged from 2 to 167. The 17 information media have been arranged in rank order in Table 2 on the basis of their media use index. Contact with neighbors was identified as the highest used information media with a frequency of 167 and it was followed by television (frequency 136), friends and relatives (frequency 132), mobile (frequency 127) and contact with SAAO (frequency 117) (Table 3).

The lowest use information media was field day with a frequency of 2. The media use index (MUI's) for the remaining information media agricultural exhibition (80), attending meeting at result demonstration (46), UAO (31), method demonstration (27), krishikotha (24), radio (18), dealers (14), attending field trip (8) and poster (7). 


\begin{tabular}{|l|c|c|c|c|}
\hline Information Media & MUI & Percent of respondents & Rank order & Average \\
\hline Individual & 167 & 83.5 & 1 & \\
\hline Neighbors & 132 & 66.5 & 3 & \\
\hline Friends \& Relatives & 117 & 58.5 & 5 & 46.1 \\
\hline SAAO & 31 & 15.5 & 8 & \\
\hline Upazila Agriculture Officer & 14 & 7.0 & 12 & \\
\hline Input dealers & 461 & \multicolumn{5}{l|}{} \\
\hline Total & \multicolumn{5}{|l|}{} & \\
\hline Group & 46 & 24.5 & 7 & \\
\hline Meeting at result demonstration & 27 & 13.5 & 9 & \\
\hline Method demonstration & 80 & 41.5 & 6 & 16.3 \\
\hline Agricultural exhibition & 8 & 4.0 & 13 & \\
\hline Field trips & 2 & 1 & & \\
\hline Field day & 163 & \multicolumn{5}{|l|}{} \\
\hline Total & \multicolumn{5}{|l|}{} \\
\hline Mass & 136 & 68.0 & 2 & \\
\hline Television & 127 & 63.5 & 4 & \\
\hline Mobile phone & 46 & 24.5 & 7 & \\
\hline Result demonstration & 24 & 12.0 & 10 & 37.6 \\
\hline KrishiKotha & 18 & 9.0 & 11 & \\
\hline Radio & 18 & 9.0 & 11 & \\
\hline Internet & 7 & 3.5 & 14 & \\
\hline Poster & 376 & & & \\
\hline Total & \multicolumn{5}{|l|}{} \\
\hline
\end{tabular}

Table 3: Rank order and Comparison of the use of individual, group and mass contact media by the vegetable growers.

This table also represents the comparison of the use of individual, group and mass contact media by the vegetable growers. This comparison was measured according to the percentage of the MUI of the different information media. The result indicated that the use of individual media is highest (46 percent) among the vegetable growers to collect relevant information. However, 38 percent respondents used mass media whereas only 16 percent of them used group information media to gather knowledge regarding vegetables cultivation.

Relationship between selected characteristics of the vegetable growers and their use of information media

Table 4 represents the relationships of the eleven selected characteristics of the vegetable growers e.g. age, education, family size, farm size, annual income, organizational participation, knowledge in vegetable cultivation, cosmopoliteness, training, innovativeness and coping with uncertainty with their extent of use of information media in receiving information on vegetable cultivation.

Among the eleven selected characteristics farmers age, family size, farm size, organizational participation, innovativeness, cosmopoliteness and agricultural knowledge had positive significant relationship with their use of information media which indicates the more these characteristics are developed, more will be the use of information media in receiving information in relation to vegetables cultivation. The result resembles the findings of Nuruzzaman [4], Latif [5], Kashem and Halim [6] and Chowdhury [7]. However, education, annual income, training and Coping with uncertainty of the farmers had insignificant relationship with their use of information media in receiving agricultural information. Nuruzzaman [4] and Kashem [8] also reported almost similar result in their studies. 


\begin{tabular}{|l|c|}
\hline $\begin{array}{l}\text { Selected characteristics of the } \\
\text { respondents }\end{array}$ & $\begin{array}{c}\text { Correlation co-efficient } \\
\text { value " } \mathbf{~}\end{array}$ \\
\hline Age & $-0.486^{* *}$ \\
\hline Education & $-0.17(\mathrm{NS})$ \\
\hline Family size & $0.375^{* *}$ \\
\hline Farm size & $0.774^{* *}$ \\
\hline Annual income & $0.071(\mathrm{NS})$ \\
\hline Organizational participation & $0.598^{* *}$ \\
\hline Cosmopoliteness & $0.491^{* *}$ \\
\hline Innovativeness & $0.491^{* *}$ \\
\hline Training & $0.615(\mathrm{NS})$ \\
\hline Coping with uncertainty & $0.067(\mathrm{NS})$ \\
\hline Knowledge in vegetable cultivation & $0.577^{* *}$ \\
\hline$* *$ Correlation is significant at the & \\
\hline 0.01 level, NS = Non- significant & \\
\hline
\end{tabular}

Table 4: Co-efficient of correlation showing relationship between the uses of information media and selected variables of the farmers.

\section{Conclusion}

In most cases the vegetable growers in the Sylhet district maintained contact with individual media specially neighbors, friends and relatives and sub assistant agriculture officer as the vital source of information. Apart from this, they also gave emphasis on agriculture related television programs and mobile phone to update their knowledge in the same field. However, they should be motivated for frequent participationin relevant organizations and extensive exposure with the society to enhance their innovativeness and agricultural knowledge and ultimately secure searching information related to modern vegetable cultivation.

\section{Bibliography}

1. Oakley P and C Garforth. Guide to Extension Training, FAO, Rome, Italy (1985).

2. Mosher AT. "An Introduction to Agricultural Extension". Agricultural Development Council, New York (1976).

3. Mehmood R. The role of mass media in diffusing modern agricultural technologies in district Sheikhupura. M.Sc. Thesis, Dept. of Rural Soc., Univ. of Agri., Faisalabad (2000).

4. Nuruzzaman M. Knowledge, Attitude and Practice of FFS and Non-FFS Farmers in Respect of IPM. M. S. (Ag. Ext. Ed.) Thesis, Department of Agricultural Extension Education, Bangladesh Agricultural University, Mymensingh (2000).
5. Latif MA. "How Farmers Receive Agricultural Information". M.Sc.(Ag. Ex. Ed.) Thesis, Department of Agricultural Extension and Teacher's Training, Bangladesh Agricultural University, Mymensingh (1974): 179.

6. Kashem MA and A Halim. "Use of Communication Media in the Transfer of Technologies to Farmers: A Farm Level Study". Department of Agricultural Extension Education, Bangladesh Agricultural Research Council, Dhaka (1991).

7. Chowdhury MSA. "Adoption of Selected BINA Technologies by the Farmers of Boyra Union in Mymensingh District". An M. S. (Ag. Ext. Ed.) Thesis, Department of Agricultural Extension Education, Bangladesh Agricultural University, Mymensingh (1997).

8. Kashem MA. "Small Farmers Constraints to the Adoption of Modern Rice Technology". The Bangladesh Development Studies 15 (1987): 18-30.

\section{Volume 3 Issue 11 November 2019 (C) All rights are reserved by MM Adhikary., et al.}

